Review Article

\title{
STUDIES ON THE NUMEROUS MEDICINAL UTILITIES OF THE PLANT URGINEA INDICA: A COMPREHENSIVE OVERVIEW
}

\author{
JUNMONI NATH ${ }^{*}$ \\ aDepartment of Pharmaceutics, Girijananda Chowdhury Institute of Pharmaceutical Sciences, Azara, Guwahati 781017 \\ Email: junmoninath2014@gmail.com
}

Received: 11 Jul 2020, Revised and Accepted: 09 Sep 2020

\begin{abstract}
Urginea indica, is an essential indigenous plant belonging to the family Liliaceae found in all parts of India on rocky and hilly areas. It is commonly known as Indian squill, True squill or Sea onion and popularly known as Bon Pollundu. A methodical literature survey from various scientific databases such as PubMed, Scopus, Web of science and Google Scholar was conducted and it has been reported that the plant, mainly its bulb contains varieties of bioactive constituents such as flavonoids, phytosterols, phenols, saponins, alkaloids, proteins, carbohydrates, steroids and tannins. The bulb and the rhizome also contains calcium, iron, commercial compounds, such as Bufadienolides, Quercetin, Allose, Mindererus spirit, Tartronic acid and Paraldehyde, which have a variety of health functional properties. Various scientific studies have proven that the plant has anticancer, antidiabetic, anthelmintic, analgesic, antibacterial, antifungal, anti-angiogenic, anti-arthritic, antioxidant, anti-inflammatory, spasmodic and cardiac stimulant activities. It also finds its use as an analgesic and in wound healing. Thus, the current review gives a comprehensive overview of the various medicinal activity of the plant Urginea indica.
\end{abstract}

Keywords: Urginea indica, Bioactive constituents, Flavonoids, Antioxidant

(C) 2020 The Authors. Published by Innovare Academic Sciences Pvt Ltd. This is an open access article under the CC BY license (http://creativecommons.org/licenses/by/4.0/) DOI: http://dx.doi.org/10.22159/ijcpr.2020v12i6.40276. Journal homepage: https://innovareacademics.in/journals/index.php/ijcpr

\section{INTRODUCTION}

Urginea indica belonging to the family liliaceae, is a glabrous herb with polytypic genus consisting of about 99 species all over the world, 9 occurring in India [1]. It is commonly called as Indian Squill or Sea onion and locally known as jungli piyaz [2]. It is a small plant growing up to a height of 45 to $60 \mathrm{~cm}$ [3]. In Ayurveda, Urginea indica is commonly known as Bon Pollundu and has find its use both in pharmaceutical as well as in agricultural sector [4]. Among the different parts of the plant, the bulb has been reported to have immense significant value mainly as antidiabetic, antioxidant, anticancer, dyspepsia, cardiac stimulant, in hypertension, arteriosclerosis, in treatment of edema, dropsy, asthma, rheumatism, gout, allergies, wound healing and to treat various other disorders [5]. The other actions accredited to $U$. indica are expectorant, anthelmintic, stomachic, purgative, digestive, diuretic, in rheumatism, scabies, skin diseases, internal pain and leprosy [6]. Various chemical constituents like tannins, phenols, alkaloids, flavonoids are present in all parts of the plant, whereas steroids are solely present in the bulb [7]. Also, the bulb contains glycosides, carbohydrates, resins, quinones and saponins [8].

Here in this review, a comprehensive overview of the various medicinal activity of the plant Urginea indica has been listed.

\section{MATERIALS AND METHODS}

A thorough literature survey of the plant $U$. indica was carried out from different scientific databases such as Scopus, PubMed, Google Scholar and Web of Science. For the online literature survey, The terms "Indian squill", "Urginea indica", "Drimia indica", "Ban Palandu", "Scilla indica" and "Kolkanda" were searched for the online literature survey. A number of book chapters, articles, web pages were obtained from online sources. This review consists of a comprehensive collection of the various literatures on the therapeutic activity of Urginea indica.

\section{Plant description}

Urginea indica is a perennial herb having fibrous roots. The roots proceeds from the base of the bulb (pear-shaped and conical) and are about six to ten inches in length. The bulbs had transparent outer scales, resembling the size of a big onion, comprising fleshy coats that are orange-brown or papery red in colour, encircling each other fully, is engrossed in the sand by three fourth. Leaves having smooth-edged grow from the bulbs in the shape of a rosette about 1$2.5 \mathrm{~cm}$ wide and $15-30 \mathrm{~cm}$ long. The flowers blossom in the month of April and May. A long, stiff, smooth succulent flower rises from the middle of the leaves with a high of about one to three feet, having close spike of whitish flowers, which stand on purplish peduncle $[9,10]$.

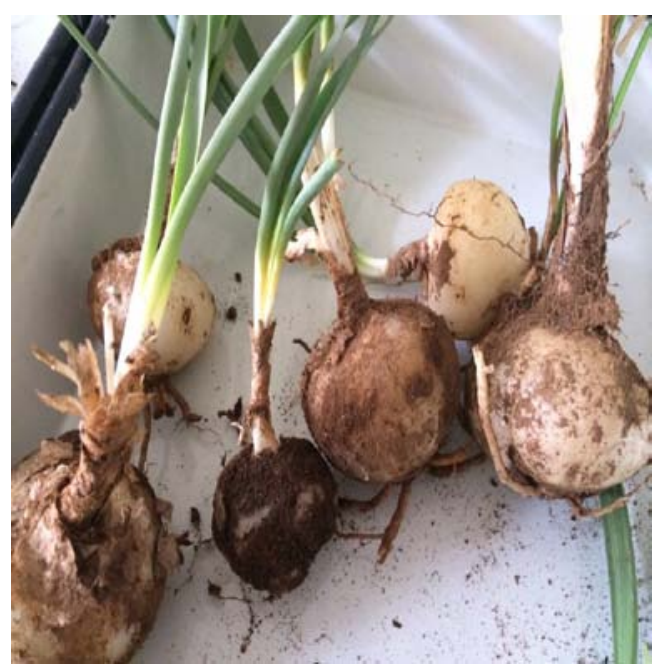

Fig. 1: Urginea indica

\section{Phytochemicals}

The main active constituents of Urginea indica are the steroidal glycosides. A number of steroidal glycosides are present in Urginea indica, among which Scillaren A and proscillaridin A are found in the highest concentration in the bulb [11]. From the blub, plenty of phytochemicals were extracted, which were found to be potentially bioactive. Other elements found in the herb include steroids, esters, 
carbohydrates, flavonoids, saponins, antifungal glycoproteins and esters. The bulb also contains steroids which were used to cure psoriasis by the indigenous people $[12,13]$. A total number of thirteen Bufadienolides were identified in both the roots and bulb [14]. Urginea indica has also been reported with a novel $29 \mathrm{kDa}$ glycoprotein that has Antifungal acitivity [15]. 0ther compounds such as quercitin (found helpful in reducing the blood pressure of individuals), paraldehyde (used as a hypnotic and sedative), mindereru's spirit (helpful in perspirations), and tartronic acid (used as oxygen scavenger) were also recognized [16-18]. Listed below is a table showing the active compounds present in Urginea indica responsible for its activity $[13,19]$ :

Table 1: Compounds present in $U$. indica and the activity they are responsible for

\begin{tabular}{lll}
\hline S. No. & Compounds & Activity responsible for \\
\hline 1 & Glucose & Acetylcholinergic, Antihepatotoxic, Antiedemic, Antivaricose, Memory enhancer \\
2 & Scillarenin & Anticarcinomic, Antirhinoviral, Cardiotonic, Pesticide \\
3 & Mannose & Anticystic \\
4 & Quercetin & Cancer preventive \\
5 & Flavones & Anti-inflammatory \\
\hline
\end{tabular}<smiles>CCC(c1ccc(=O)oc1)C(C)(O)C1CCC2=CC(O)CCC2(C)CC1</smiles>

Scillarenin<smiles></smiles>

Quercetin

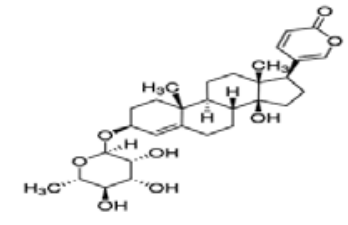

Proscillardin<smiles>O=C(O)C(O)C(=O)O</smiles>

Tartronic acid<smiles>CCC(C=CC1CCC2C3CCC4(CCCC12C)CCC(O)CC4C3C)C(C)C</smiles>

Stigmasterol

Fig. 2: Structures of some compunds found in $U$. indica

\section{Pharmacological and therapeutic activity}

The various pharmacological/therapeutic activity of the plant are listed below:

\section{Antioxidant}

Flavonoids, carotenoids, polyphenolics are some of the popular natural antioxidant substances reported in Urginea indica. A methanolic extract of the bulbs of $U$. indica at a concentration of 150 $\mu \mathrm{g} / \mathrm{ml}$ showed antioxidant activity by DPPH assay. In this in vitro study, different concentrations of the methanolic extracts were taken ranging from 30 to $150 \mu \mathrm{g} / \mathrm{ml}$. Here the extracts showed the varying percentage of activity i. e, from $98.10 \%$ to $99.14 \%$. However, this report could not be considered to be operative enough as the doses showing antioxidant activity were too high, also to compare the DPPH radical scavenging activity; there was no positive control used [20]. In another in vitro study, the methanolic extract of $U$. indica showed antioxidant activity by DPPH assay. Different concentrations of $20,40,60,80,100$ and $200 \mu \mathrm{g} / \mathrm{ml}$ of the extract were used to evaluate the DPPH radical scavenging activity. The IC50 value of the extract was found to be $51.87 \mu \mathrm{g} / \mathrm{ml}$, which was comparable to the gallic acid IC50 value of $39.91 \mu \mathrm{g} / \mathrm{ml}$ [21].

Also, it was reported that the bulbs of $U$. indica have proanthocyanidin and phenolic substances that are responsible for its antioxidant and free radical scavenging activities [22]. Again, in another in vitro study, chloroform, ethyl acetate and methanol extracts of the bulbs were reported to have antioxidant activity. Different concentrations of $10,20,40$, and $60 \mu \mathrm{g} / \mathrm{ml}$ of the extract were used to evaluate the DPPH free radical scavenging activity. The IC50 values of $24.98,23.00$, and $22.61 \mu \mathrm{g} / \mathrm{ml}$ were found, respectively where the methanol extract IC50 value was found to be alike to ascorbic acid $(22.33$ $\mu \mathrm{g} / \mathrm{ml})$. The study reported that methanolic extract has the highest activity, at $95.50 \%-97.57 \%$, followed by chloroform $(93.38 \%-95.91 \%)$ and ethyl acetate (86.40\%-88.24\%) [23].

\section{Antidiabetic}

An antidiabetic study was conducted by Gupta et al. of the ethanolic extract of bulbs (U. indica) against streptozotocin-induced diabetes rats. Glibenclamide $(10 \mathrm{mg} / \mathrm{kg})$ was used as the standard drug. The extract was used as $750 \mathrm{mg} / \mathrm{kg}$ and $1.5 \mathrm{~g} / \mathrm{kg}$ of body weight. Both the extract and the drug were used orally for a period of $14 \mathrm{~d}$. Within 120 min of administration of the extract at the dose of $1.5 \mathrm{~g} / \mathrm{kg}$ considerable decrease in the blood glucose levels was shown in the diabetic rats. Along with the reduction in the blood sugar level, total cholesterol and triglyceride levels were also found to reduce by the extract. Moreover, matched with the group of untreated rats, the levels of high-density lipoproteins were found to improve. The histopathological study revealed that the extract partially repaired the 
damaged cellular population of pancreatic islets in rats. The results of the experiments suggested that ethanolic extracts of $U$. indica has significant antidiabetic effects on STZ-induced diabetic rats [24].

\section{Anthelmintic}

The bulbs of $U$. indica has been reported to treat helminthiasis, which is a macroparasitic disease. It is caused by the parasitic worms in humans and animals. In an in-vivo study, an aqueous extract obtained from the leaf, scape, and bulb of the plant was tested for anthelmintic activity against earthworm (Pheretima posthuma) due to its anatomical and physiological resemblance to human intestinal roundworm parasites. The extract, at the dose of 5 $\mathrm{mg} / \mathrm{ml}$, paralysis the earthworms at $41 \mathrm{~min}$ and death at $50 \mathrm{~min}$. On the other hand, albendazole $(5 \mathrm{mg} / \mathrm{ml})$, a positive control in this study, showed paralysis at $92 \mathrm{~min}$ and the death of earthworms at $110 \mathrm{~min}$. The above study revealed that the crude extract of the bulbs was highly effective against earthworms and was equally potent to albendazole at a similar concentration. On the basis of this study, it can be suggested that the active molecule/s of the plant certainly have a higher potential. However, this needs further advanced study to reach a final conclusion [25].

\section{Antibacterial}

$U$. indica has also been reported to have antimicrobial efficacy. In a study, it was found that the methanolic extracts obtained from the leaves, stem and roots were effective against different bacteria like S. aureus, E. coli, B. subtilis, A. niger, S. epidermidis, C. albicans and P. aeruginosa at a dose of $2 \mathrm{mg} / 20 \mu \mathrm{l}$. The standards used were Penicillin and streptomycin against bacteria and clotrimazole against fungi at 10 $\mu \mathrm{g} / 20 \mu \mathrm{l}$. Among all the extracts obtained from different parts, the methanolic root extract revealed the highest activity, showing Inhibition Zone Diameter values of 15.06, 14.33, and $12.33 \mathrm{~mm}$ against B. cereus, S. epidermidis, and S. aureus, respectively [26].

Potent inhibitory action was reported by aqueous bulb extract of $U$. indica against gram-negative bacteria (Shigella flexneri, Pseudomonas aeruginosa and Vibrio cholerae), gram-positive bacteria (Bacillus brevis, B. subtilis, B. licheniformis and Streptococcus aureus) and fungus (Candida kruse), showing inhibition zone diameter (IZD) ranging between 19 and $28 \mathrm{~mm}$ at $200 \mu \mathrm{l}$ [27].

Another study showed that the methanolic bulb extracts showed activity against Escherichia coli, Staphylococcus aureus, and P. aeruginosa, with an IZD range of $0.7-1.4 \mathrm{~cm}$ at 50,100 , and 150 $\mathrm{mg} / \mathrm{ml}$. The results were compared to levofloxacin at a concentration of $500 \mathrm{mg} /$ disc, although this concentration looks to be too high for an in vitro study and may not be considered authentic, showing an IZD of 1.3 and $1.4 \mathrm{~cm}$ against P. aeruginosa and E. coli, respectively. In this study, pure methanol was used as a control. The results were correlated with its traditional use in wound healing [28].

\section{Antifungal}

U. indica also has been reported to have antifungal activity. A 29-kDa glycoprotein found in the bulbs of $U$. indica were shown to have antifungal activity against some plant pathogenic fungus-like, Rhizoctonia solani, Fusarium oxysporum, Alternaria tenuissima and Sclerotium rolfsii. The maximum inhibition was found against $\mathrm{F}$. oxysporum at $10 \mu \mathrm{g} /$ well [29]. In another study, protein chitinase present in the bulbs was reported to show activity against the plant pathogenic fungus R. solani and F. oxysporum [30].

\section{Anti-inflammatory and analgesic}

In an in-vitro study, the ethanolic bulb extract of $U$. indica was administered in Swiss albino rats to evaluate its anti-inflammatory and analgesic activities. The ethanolic extract used was fractionated from the methanol extract of oven-dried material, was used at an oral dose of $1.5 \mathrm{~g} / \mathrm{kg}$ showed significant anti-inflammatory activity against carrageenan-induced oedema in rats, having a range of inhibition between $18.68 \%$ and $29.78 \%$ at $1-4 \mathrm{~h}$ when compared to the untreated control. On the other hand, the standard drug (ibuprofen) inhibited oedema at an oral dose of $6 \mathrm{mg} / \mathrm{kg}$ by a range between $23.07 \%$ and $41.84 \% 1-4 \mathrm{~h}$ post-treatment. With a similar oral dose, i.e., $1.5 \mathrm{~g} / \mathrm{kg}$, the extract also exhibited analgesic activity in rats using a hot plate assay. The hot plate pain perception in rats was raised for up to $3 \mathrm{sec}$ by the extract compared to the untreated rats, whereas ibuprofen with an oral dose of $6 \mathrm{mg} / \mathrm{kg}$ showed pain perception for $11 \mathrm{sec}$ till $4 \mathrm{~h}$ [31].

\section{Anticancer}

Methanolic extract of Urginea indica (MEUI) was reported to have anticancer activity against Ehrlich Ascites Carcinoma (EAC) cells in swiss albino mice. Swiss albino mice were inoculated with EAC cells and the reduction ability of EAC cells was observed by Rudimentary assessment of Methanolic extract of Urginea indica. The reduction of average tumor weight was measured to find out anti-cancer efficacy of MEUI. This study revealed significant weight variation at $4 \mathrm{X}$ doses of MEUI indicating loss of tumor weight. The weight variation study of tumour by MEUI showed a $47.66 \%$ decrease at $2 x$ dose and $65.10 \%$ decrease in weight at $4 \mathrm{x}$ doses in total ascites fluid weight versus control, which was statistically highly significant $(\mathrm{p}=0.003)$. After $30 \mathrm{~d}$ of observation, no mice survived in the control group, whereas 3 mice were alive in the group treated by MEUI at $2 \mathrm{x}$ dose and 5 mice were alive in the group treated with MEUI at $4 \mathrm{x}$ dose. This study showed that MEUI has anticancer activity [32].

\section{Bronchodilator and cardiac stimulant}

An aqueous ethanol extract of the bulb was studied in rabbit tracheal and guinea pig atrial preparations. The extract inhibited contractions induced by carbachol $(1 \mu \mathrm{M})$ and $\mathrm{K}+(80 \mathrm{mmol})$ in rabbit tracheae, similarly to dicyclomine. The results suggested the presence of $\mathrm{Ca} 2+$-channel blocking and anticholinergic mechanisms of the extract. The extract $(0.01-1 \mathrm{mg} / \mathrm{ml})$ increased the force of guinea pig atrial contractions without affecting their rate. This effect was perhaps mediated through the combined mechanism of an anticholinergic and $\mathrm{Ca} 2+$ antagonist accompanied by an inotropic effect. This in vitro report gave an idea about the possible role of $U$. indica bulbs in bronchial diseases such as asthma and bronchitis. However, further studies with in vivo/clinical models are warranted before its use as a bronchodilator. Its purified fraction(s) or constituent(s) should be used to improve its efficacy and also to reduce dose sizes [33].

\section{other medicinal use}

$U$. indica has also find its use in milder cases of heart insufficiency and also for diminished kidney capacity. An inulin like substance named Sinistrin is extracted from squill for use as a marker in diagnosis of renal problems [34]. The extract of $U$. indica has also proved effective in muscle pain and developed as an analgesic [35]. Studies has also reported larvicidal action of Urginea indica against Aedes larvae causing dengue fever. The lypholised aqueous extract of $400 \mu \mathrm{l}$ showed $100 \%$ mortality of the larvae within fifteen hours [13]. Again, local application of dichloromethane extract obtained from the bulbs of $U$. indica also showed trauma healing activity in rats with skin trauma [36].

\section{CONCLUSION}

This study concludes that various extracts of $U$. indica, mainly the extracts of the bulb have shown significant anthelmintic, antibacterial, antifungal, anticancer, antioxidant, antidiabetic, bronchodilator, anti-inflammatory, analgesic, and wound healing activities in different in vitro and in vivo models due to the presence of various bioactive compounds and can be a potential source of new useful drug. Although the plant has been used in Ayurveda for many years, no clinical studies are performed on this plant. Hence, there is quiet a decent possibility for upcoming research based on clinical trials of this plant.

However, Urginea indica is favorable for further studies of bioactive compounds and isolation of a new drug. The plant species needs immediate protection, propagation and conservation as it is under the threatened category.

\section{FUNDING}

Nil

\section{AUTHORS CONTRIBUTIONS}

All the authors have contributed equally. 


\section{CONFLICT OF INTERESTS}

Declared none

\section{REFERENCES}

1. Deepak AV, Thippeswamy G, Shivakameshwari MN, Salimath BP. Isolation and characterization of a $29-\mathrm{kDa}$ glycoprotein with antifungal activity from bulbs of Urginea indica. Biochem Biophys Res Commun 2003;311:735-42.

2. Bashir S, Abbas S, Gilani AH, Khan A. Studies on bronchodilator and cardiac stimulant activities of Urginea indica. Bangladesh J Pharmacol 2013;8:249-54.

3. Bozorgi M, Amin G, Shekarchi M, Rahimi R. Traditional medical uses of Drimia species in terms of phytochemistry, pharmacology, and toxicology. J Traditional Chinese Med 2017;37:124-39.

4. Aswal S, Kumar A, Semwal RB, Chauhan A, Kumar A, Lehmann J, et al. Drimia indica: a plant used in traditional medicine and its potential for clinical uses. Medicina 2019;55:255

5. Raj MS, Kameshwari MN, Tharasaraswath KJ, Shubharani R. Qualitative and quantitative analysis of phytochemicals in two different species of Urginea. Int J Pharm Life Sci 2017;8:5433-8.

6. Kirtikar KR, Basu BD. Indian medicinal plants. Dehradun. International book distributors; 1987. p. 2.

7. Chittoor MS, Binny AJ, Yadlapalli SK, Cheruku A, Dandu C, Nimmanapalli Y. Anthelmintic and antimicrobial studies of Drimia indica (Roxb.) Jessop. bulb aqueous extracts. J Pharm Res 2012;5:3677-86.

8. Pandey D, Gupta AK. Antimicrobial activity and phytochemical analysis of Urginea indica from bastar district of Chhattisgarh. Int J Pharm Sci Rev Res 2014;26:273-81.

9. Kameshwari S. Biosystematics studies of some members of Liliaceae (Doctoral dissertation, Ph. D. thesis. Mysore University, Mysore); 1992.

10. Kameshwari MS, Saraswathi KT, Muniyamma M. Morphological variations in populations of Urginea indica Kunth. Liliaceae. Appl Nat Sci 2010;2:280-9.

11. Bayazı TV, Konar V. Analgesic effects of scilliroside, proscillaridin-a, and taxifolin from squill bulb (Urginea maritima) on PAINS. Digest J Nanomaterials Biostructures (DJNB) 2010;5:457-65.

12. Haynes GS. The pharmacological action of digitalis, strophanthus, and squill on the heart. Biochem J 1906;1:62-87.

13. Lakshman $\mathrm{AB}$, Paramasivam G. Biosystematics studies on medicinal plant Urginea indica Kunth. liliaceae-a review. Int J Pharm Life Sci 2012;3:1394-406.

14. Jha S, Sen S. Bufadienolides in different chromosomal races of Indian squill. Phytochemistry 1981;20:524-6.

15. Deepak AV, Thippeswamy G, Shivakameshwari MN, Salimath BP. Isolation and characterization of a $29-\mathrm{kDa}$ glycoprotein with antifungal activity from bulbs of Urginea indica. Biochem Biophysical Res Communications 2003;311:735-42.

16. Armstrong DL, Battin MR. Pervasive seizures caused by hypoxic-ischemic encephalopathy: treatment with intravenous paraldehyde. J Child Neurol 2001;16:915-7.

17. Bizot PM, Bailey BR, Hicks PD. Inventors; Nalco Chemical Co, assignee. Use of tartronic acid as an oxygen scavenger. United States patent US 5,750,037; 1998

18. Gupta A, Singh SK, Yadav AK. Pharmacological evaluation of the antidiabetic activity of Urginea indica in laboratory animals. Int J Nutr Pharmacol Neurol Diseases 2015;5:63.
19. Harini SS, Leelambika L, Kameshwari S, Sathyanarayana N. Optimization of DNA isolation and PCR-RAPD methods for molecular analysis of Urginea indica Kunth. Int J Integrative Biol 2008;2:138-44.

20. Panduranga MG, Mamtharani DR, Tejas TS, Niranjan MS. Phytochemical analysis, in vitro anti-bacterial and antioxidant activities of wild onion sps. Int J Pharma Bio Sci 2011;2:230-7.

21. Mahato D, Sahu AP, Sharma HP. Phytochemical and antioxidant evaluation of Urginea indica Kunth. Indian J Traditional Knowledge 2018;17:783-8.

22. Rajput B, Golave A, Yadav S, Jadhav JP. Total phenolic concentrations and antioxidant activities in Drimia sp. J Herbs, Spices Med Plants 2018;24:28-36.

23. Soni LK, Jain SK, Dobhal S, Parasher P, Dobhal MP. Free radical scavenging activity of Urginea indica, Alhagi maurorum, crinum asiaticum and prosopis cineraria. Int J Pharm Phytochem Res 2015;7:311-4.

24. Gupta A, Singh SK, Yadav AK. Pharmacological evaluation of the antidiabetic activity of Urginea indica in laboratory animals. Int J Nutr Pharmacol Neurol Diseases 2015;5:63.

25. Chittoor MS, Binny AJ, Yadlapalli SK, Cheruku A, Dandu C, Nimmanapalli Y. Anthelmintic and antimicrobial studies of Drimia indica (Roxb.) Jessop. bulb aqueous extracts. J Pharm Res 2012;5:3677-86.

26. Pandey D, Gupta AK. Antimicrobial activity and phytochemical analysis of Urginea indica from bastar district of Chhattisgarh. Int J Pharm Sci Rev Res 2014;26:273-81.

27. Thatoi HN, Panda SK, Rath SK, Dutta SK. Antimicrobial activity and ethnomedicinal uses of some medicinal plants from similipal biosphere reserve, Orissa. Asian J Plant Sci 2008;7:260-7.

28. Panduranga MG, Mamtharani DR, Tejas TS, Niranjan MS Phytochemical analysis, in vitro anti-bacterial and antioxidant activities of wild onion sps. Int J Pharma Bio Sci 2011;2:230-7.

29. Deepak AV, Thippeswamy G, Shivakameshwari MN, Salimath BP. Isolation and characterization of a $29-\mathrm{kDa}$ glycoprotein with antifungal activity from bulbs of Urginea indica. Biochem Biophys Res Commun 2003;311:735-42.

30. Shenoy SR, Kameshwari MS, Swaminathan S, Gupta MN. Major antifungal activity from the bulbs of Indian squill Urginea indica is a chitinase. Biotechnol Progress 2006;22:631-7.

31. Rahman MM, Chowdhury JA, Habib R, Saha BK, Salauddin AD, Islam MK. Anti-inflammatory, anti-arthritic and analgesic activity of the alcoholic extract of the plant Urginea indica kunth. Int I Pharm Sci Res 2011;2:2915.

32. Hossain MS, Khalequeuzzaman M, Hasan MN, Islam MA, Rana MS. Evaluation of anticancer potential of the bulbs of Urginea Indica. Br J Med Health Sci 2020;2:117-21.

33. Bashir S, Abbas S, Gilani AH, Khan A. Studies on bronchodilator and cardiac stimulant activities of Urginea indica. Bangladesh J Pharmacol 2013;8:249-54.

34. Blumenthal $\mathrm{M}$. The complete german commission $\mathrm{E}$ monographs: Therapeutic Guide to Herbal Medicines; 1999.

35. Bayazı TV, Konar V. Analgesic effects of scilliroside, proscillaridin-a and taxifolin from squill bulb (Urginea maritima) on PAINS. Digest J Nanomaterials Biostructures (DJNB) 2010;5:457-65.

36. Mikail HG, Karvouni H, Kotsiou A, Tesseromatis C, Magiatis P. New alkylresorcinols from a lipophilic extract of Urginea indica L. bulbs showing experimental trauma healing activity. Fitoterapia 2015;101:41-5. 